Int. J. Electrochem. Sci., 15 (2020) 1242 - 1263

International Journal of

ELECTROCHEMICAL

SCIENCE

$\underline{\text { www.electrochemsci.org }}$

\title{
Electrochemical Behavior of Austenitic Stainless Steels Exposed to Acetic Acid Solution
}

\author{
K. Zuñiga-Diaz ${ }^{1,3}$, C.D. Arrieta-Gonzalez ${ }^{2}$, J. Porcayo-Calderon ${ }^{3, *}$, J.G. Gonzalez-Rodriguez ${ }^{3}$, M. \\ Casales-Diaz ${ }^{1}$, L. Martinez-Gomez, \\ ${ }^{1}$ Instituto de Ciencias Físicas, Universidad Nacional Autónoma de México, Avenida Universidad s/n, \\ 62210 Cuernavaca, MOR, México. \\ ${ }^{2}$ Tecnológico Nacional de México - Instituto Tecnológico de Zacatepec, Calzada Instituto Tecnológico \\ 27, 62780 Zacatepec, MOR, México \\ ${ }^{3}$ CIICAp, Universidad Autónoma del Estado de Morelos, Avenida Universidad 1001, 62209 \\ Cuernavaca, MOR, México. \\ ${ }^{4}$ Corrosion y Protección (CyP), Buffon 46, 11590 México City, México. \\ *E-mail: jporcayoc@gmail.com
}

doi: $10.20964 / 2020.02 .13$

Received: 17 September 2019 / Accepted: 30 October 2019 / Published: 31 December 2019

In this work, an electrochemical evaluation was carried out for different austenitic stainless steels in an acetic acid solution based on Italian Decree text. The electrochemical performance of the steels was determined by electrochemical techniques such as potentiodynamic polarization curves, measurements of the open circuit potential, linear polarization resistance, and electrochemical impedance spectroscopy. Although the steels show a high corrosion resistance, the specific performance of each one depends on both the chemical composition and the microstructural characteristics. It was found that an increase in the $\mathrm{Cr}$ content decreases the corrosion resistance, but precipitates and inclusions decrease it considerably, thus favoring the release of metallic ions into the electrolyte. In addition, the capacitive properties of the protective oxide depend on both the degree of $\mathrm{Cr}$ enrichment degree and its thickness.

Keywords: Corrosion, austenitic stainless steel, food contact, electrochemical techniques, acetic acid.

\section{FULL TEXT}

(C) 2020 The Authors. Published by ESG (www.electrochemsci.org). This article is an open access article distributed under the terms and conditions of the Creative Commons Attribution license (http://creativecommons.org/licenses/by/4.0/). 